\title{
Practical Experience of Managing the Distributed E-Learning System «SPIDER» in the Preparation of Students of the Faculty of Economics and Finance at the North-West Institute of Management, Branch of RANEPA
}

\author{
Alexey P. Isaev*, Tatyana V. Vasilyeva
}

Russian Presidential Academy of National Economy and Public Administration (North-West Institute of Management of RANEPA), Saint-Petersburg, Russian Federation; *isaev-ap@ranepa.ru

\begin{abstract}
We consider examines the place and role of E-learning in the Internet economy, the nature and features of the distributed system of E-learning, the practical experience of the managing of distributed E-learning system on the example of DELS "SPIDER". This system is used in the preparation of students of the faculty of Economics and Finance at the North-West Institute of Management, branch of RANEPA. In the article the analysis of the impact of the Internet on learning, history of development of E-learning, the most important elements of the conceptual apparatus of E-learning, the essence of distributed E-learning system "SPIDER". We identify a number of constraining factors for its implementation in the educational process. We identify a number of constraining factors for implementation in the educational process The method of teaching students with the use of modern Internet technologies based on DELS "SPIDER" :The authors formulated four principles of E-Learning: personal approach, calm study temp, favorable psychological climate, modern material and technical base in the institute and relax room for the teachers.
\end{abstract}

Keywords: electronic learning, E-learning, Internet economy, IT technologies. Internet business, information technology. internet technology, LMS, MOOC, DELS "SPIDER"

For citing: Isaev A. P., Vasilyeva T.V. Practical Experience of Managing the Distributed E-Learning System «Spider» in the Preparation of Students of the Faculty of Economics and Finance at the North-West Institute of Management, Branch of RANEPA // Administrative consulting. 2019. No. 11. P. 69-75.

\section{Практический опыт управления распределенной системой электронного обучения "SPIDER" при подготовке студентов факультета экономики и финансов Северо- Западного института управления РАНХиГС}

\section{Исаев А. П. ${ }^{*}$, Васильева Т.В.}

Российская академия народного хозяйства и государственной службы при Президенте Российской Федерации (Северо-Западный институт управления РАНХиГС), Санкт-Петербург, Российская Федерация, *isaev-ap@ranepa.ru

\section{PEФЕРAT}

В статье рассматривается роль электронного обучения в интернет-экономике, сущность и особенности распределенной системы электронного обучения, практический опыт управления распределенной системой электронного обучения на примере DELS "SPIDER". Данная система используется при подготовке студентов факультета экономики и финансов Северо-Западного института управления-филиала РАНХиГС. В статье проведен анализ влияния интернета на обучение, история развития электронного обучения, выделены наиболее важные элементы понятийного аппарата электронного обучения, сущность распределенной системы электронного обучения "SPIDER". Выявлен ряд сдерживающих факторов для его реализации в образовательном процессе. Выявлен ряд сдерживающих факторов для реализации в учебном процессе методики обучения студентов с исполь- 
зованием современных интернет-технологий на базе DELS "SPIDER". Авторы сформулировали четыре принципа электронного обучения: персональный подход, спокойный темп обучения, благоприятный психологический климат, современная материально-техническая база в институте и комната отдыха для преподавателей.

Ключевые слова: электронное обучение, интернет-экономика, интернет-бизнес, информационные технологии, интернет-технологии, LMS, MOOC, DELS "SPIDER"

Для цитирования: Isaev A. P., Vasilyeva T. V. Practical Experience of Managing the Distributed E-Learning System Spider in the Preparation of Students of the Faculty of Economics and Finance at the North-West Institute of Management, Branch of RANEPA // Управленческое консультирование. 2019. № 11. С. 69-75.

\section{Historical aspects of E-learning}

The system of higher education in Russia was finally formed by the beginning of the twentieth century. This system was represented by three main types of educational institutions, in the formation and development of each of which European pedagogical ideas were directly or indirectly reflected. Institutions of higher education in Russia had many of their national features, due, firstly, to the specifics of European ideas in Russian pedagogical thought and, secondly, to the socio-economic and national-cultural characteristics of the development of Russia.

The whole history of the existence and development of human society is inextricably linked with the creation, transfer, processing and storage of information [6, p. 51]. There is several information revolutions associated with significant transformations of social relations due to fundamental changes in the field of information processing [7, p. 80].

The development of information technology began with the advent of writing, and then printing. New technologies created new forms of employment:

- in the XII-XIX centuries - the publication of books, magazines and newspapers;

- in the late XIX - early XX century - telegraph and telephone;

- in the middle of the XX century - a television.

The emergence of electronic computers based on information technology has radically changed the structure of the economy. The emergence of electronic computers has turned intelligent technology into the most important tool for system analysis, the basis for making management decisions [8, p. 46].

The main stages of the world information revolution are: the Neolithic revolution, iron revolution, the emergence of writing, the invention of printing; the appearance of the telegraph, telephone, radio and television; the emergence of electronic computers, the creation of the Internet [4, p. 41].

\section{The impact of the Internet on learning}

The Internet allows you to get the maximum effect from the learning process, by increasing the freedom in choosing the time for studying e-learning courses, choosing the time for studying depending on the student's desire [10, p. 52]. The Internet allows you to make the teaching process in higher education more student-oriented [3, p. 84]. This trend implies a greater consideration of the individual characteristics of each student who has the opportunity to express all ideas and questions during the lecture in the virtual classroom, and each student question can be saved for further consideration and in-depth study.

Students of the course receive an opportunity to independently choose the pace of the course. Moreover, a student can take a certain level or stage of the course for as long as he needs to master it.

The advantages provided by the Internet in organizing the collaboration of the teacher (tutor) and the student allow the simultaneous (joint) use and editing of not only text 
materials, but also graphics, audio and video. Joint activities allow not only to be included in a single learning process, but creates opportunities for interaction not only with the student (community), but also with the teacher in real time through the virtual classroom and other elements provided by the selected e-learning system.

When implementing educational programs or their parts using exclusively e-learning an educational organization independently and (or) using the resources of other organizations:

- creates conditions for the functioning of the electronic information and educational environment, which ensures that students master the educational programs or their parts in full, regardless of the location of the students;

- provides identification of the student's personality, the choice of the method of which is carried out by the organization independently;

- provides the monitoring of compliance with the conditions of the events in which the training results are assessed.

The implementation of the educational process in accordance with the established procedure involves not only the organization's online resources, but also the local regulatory base governing their involvement in the educational process [5, p. 60].

\section{The place of E-Learning in the Internet economy}

With the advent of the Internet from the electronic economy there is an Internet economy, which is a systemically organized, multi-level structure built on the basis of the relationship between economic agents on the Internet. The beginning of the development of the Internet economy can be attributed to 1983, when the process of integration of individual local networks and established a single unified data network "Internet", the name for which was the name of the data Protocol (Internet Protocol) [2, p. 100].

In addition to the development of such areas as Internet commerce, Internet banking, Internet consulting, Internet insurance and a number of others within the Internet economy, the sphere of E-learning is developing rapidly, which is directly related to the spread of the Internet in the world and in Russia in particular.

E-learning is a form of learning, a purposeful, system-organized process of interaction between participants in the educational process, built on the use of Internet technologies [11, p. 18].

Internet technologies, being a consequence of the development of information technologies, cover all elements of the Internet economy system [8, p. 338].

Internet business is one of the forms of evolutionary development of E-business, which, in turn, is a subsystem of E-economy based on information technology [4, p. 53].

Thus, E-learning (electronic learning, online learning) is one of the areas of Internet business, which is a structural element of the Internet economy based on Internet technologies [11, p. 74].

\section{The most important elements of the conceptual apparatus of E-learning}

The most important elements that significantly influence the integration of online courses in the educational process are the following:

- the formation of a single conceptual apparatus;

- creation of a single information field in the educational organization itself;

- the formation of a local regulatory base;

- motivation of authors of learning courses to update the content of their course and to support it.

The introduction of online courses in the educational process, affects not only the changing role of the teacher, new requirements are imposed on the student.

The effectiveness of online courses in the educational process depends not only on the correct setting of e-learning goals, but also on the possibility of achieving these 
goals with the help of specific tools. Typically, this tool is an e-learning system (LMS, E-Learning Management System).

Educational platform is online service that allows different participants to place educational materials, build personalized learning paths, store information about the results of the development of disciplines.

The most famous educational platforms are Universarium, Coursera, the Russian national platform "Open Education", Netology.

Massive open online courses (MOOC) are hosted on a variety of educational platforms. The main requirements for such platforms can be formulated as:

1) the availability of the platform;

2) platform performance;

3) platform support for a minimum set of software interface functions;

4) support for account-based pass-through authentication;

5 ) availability of published minimum technical requirements and requirements for the versions of the user's software supported by the platform.

The Russian portal "Open education" is a modern educational platform offering online courses in the basic disciplines of bachelor's and master's degrees studied in Russian universities.

All courses placed on the platform are developed in accordance with the requirements of Federal state educational standards and meet the requirements for the results of educational programs implemented in universities. Upon completion of training, the student can receive a certificate. In order to be able to final testing is necessary to fulfill the requirements of the course evaluation system and make payment.

\section{Experience of E-learning system management at the Faculty of Economics and Finance at the North-West Institute of Management in St. Petersburg}

Virtually every institution of higher education applies some form of distance learning, by outsourcing or independently developing the necessary software for this. In the process of informatization of education, there is a massive connection of educational institutions to the Internet, educational portals and network libraries are being developed, therefore one of the most promising forms of distance learning is ELearning, based on the Internet, one of the global computer networks connecting entire continents [9, p. 36].

Distributed E-learning system "SPIDER" (DELS "SPIDER") is a multifunctional modular complex with integrated interactive elements of distance learning, subordinated to a single control center and allows you to organize the educational process with the use of modern Internet technologies [4, p. 46].

The main purpose of the DELS "SPIDER" is an information association through the Internet of students-economists and teachers of the Department of Economics and Finance of the North-West Institute of management [1, p. 16].

The method of teaching students with the use of modern Internet technologies based on DELS "SPIDER" takes into account such important factors as the curiosity of students and the desire for novelty, offering a dynamic structure of the lesson, combining both classical teaching methods and innovative ones.

However, despite all the advantages of such a methodology of training, it is possible to identify a number of constraining factors for its implementation in the educational process [4, p. 76].

1. The absence of officially established standards for accounting for work of this type when calculating the academic load of a teacher of a higher educational institution.

2. The need to modernize the classrooms and the organization of additional computer classes. 
3. The low level of computer literacy among a large group of students of humanitarian and socio-economic specialties.

4. The need for additional costs for the continuous modernization and maintenance of the "SPIDER" in connection with the rapid development of Internet technologies.

5. The organization of a dynamic update of information on the site, coming from teachers.

6. The need for special training of teachers to transition to this system of learning. A serious problem of the organization of Internet-based education is some misunderstanding by teachers of the prospects for introducing Internet technologies into the educational process. It is precisely with this that the difficulties of recruiting network teachers are connected.

7. In some cases, there is the problem of student interaction with the teacher in remote mode. Practical experience has shown that students have difficulties in the style of addressing the network teacher: they cannot clearly formulate their question while communicating in the forum, in the chat, in the Dialog system as part of the training course. Despite the fact that the modern generation devotes a lot of time to virtual communication with each other, the skill of individual business communication with an adult person, with the teacher, is very poorly developed among them.

Despite a number of the aforementioned constraints on the implementation of this training system, at present it is actively used at the Faculty of Economics and Finance at the North-West Institute of Management in St. Petersburg.

Four principles of E-Learning in the DELS "SPIDER" are presented on Fig 1.

This DELS "SPIDER" is actively used in the preparation of students of the faculty of Economics and Finance at the North-West Institute of Management, branch of RANEPA, at the present time.

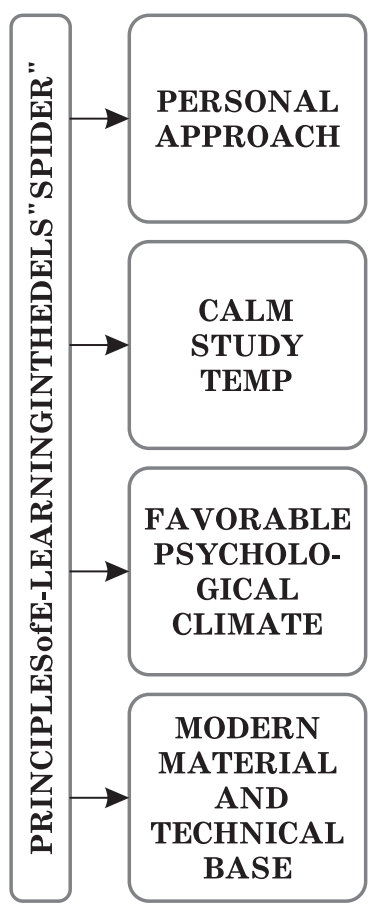

The teacher exists for a student, not a student for a teacher The teacher should use all possible means of communication with the students to be in constant contact

The student should choose a convenient way to communicate with the teacher

Do not set time limits

Do not set limits on the number of attempts to perform tasks The only restriction is to complete assignments before the exam date

The teacher must unite the student team

The teacher must distribute the students to friendly teams that will complete the tasks together

The teacher must understand the nature of each student and try to uncover all the abilities of the student

Wi-Fi

Computer classes are air-conditioned

High Internet speed in computer classes, equipped with modern PCs

Relax room for teachers

Fig. 1. Principles of E-Learning in the DELS "SPIDER" [4, p. 77] 
All in all, the article above presents the practical experience of managing the distributed E-learning system «Spider» at the Faculty of Economics and Finance at the NorthWest Institute of Management in St. Petersburg.

The first projects of electronic (online) learning in the world under the term "Elearning" appeared as early as the 1990s, however, they really became a mass phenomenon only in the mid-2000s. Today, the volume of the global E-learning market is estimated at $\$ 90$ billion, its growth rate exceeds $25 \%$ per year. Over the past 10 years, E-learning, distance learning technologies have become an integral part of a number of national educational systems. This trend is relevant for Russia.

The Federal Law No. 273-FZ "On Education in the Russian Federation", which entered into force in 2012, regulatory introduced the concepts of E-learning and distance learning technologies into the main educational process.

The Internet for the modern generation is a "natural habitat", an integral part of their life. The current generation of the information economy is learning more through visual images than previous generations, since the real world is rich in visual stimuli [2, p. 78].

\section{References}

1. Vasilieva T. V., 2008. Information and educational network «SPIDER». Monograph. St. Petersburg. IMC "NVSh - SPb". $112 \mathrm{p}$.

2. Vasilieva T.V., 2018. Internet Economy in Russia. Monograph. St. Petersburg. IMC "NVSh SPb". $159 \mathrm{p}$

3. Vasilieva T.V., 2009. Information and communication technologies in the system of higher education. Monograph. St. Petersburg. IMC "NVSh - SPb". 160 p.

4. Vasilieva T. V., 2018. E-Learning in Russia. St. Petersburg. IMC "NVSh - SPb". 162 p.

5. Karlovskaya E. A., Maskiyanova T.V., 2011. Russia in the 21st Century: Model of Sustainable Development. Monograph. Book 4. Novosibirsk : CIB-PRINT. P. 49-120.

6. Konovalova T. A., 2012. The methodology of a comprehensive assessment of the effectiveness of a mono-industrial city (on the example of Sosnovy Bor, Leningrad Region) // Discussion [Diskussiya]. No. 10. P. 51-58.P. 51-58.

7. Konovalova T.A., 2012. Features of the economic development of single-industry towns of strategic importance // Kazan Science [Kazanskaya nauka]. No. 7. P. 80-83.

8. Kuganov V.G., Kozlova V.M. 2019. Prospects for the Mobile Commerce Market in the Digital Economy // Economic Vector [Ekonomicheskii vektor]. No. 1 (16). P. 45-48.

9. Kudryashov V.S., 2017. The implementation of cluster policy for the economic development of Russian regions // Economy and management: problems, solutions [Ekonomika i upravlenie: problemy, resheniya]. No. 1. P. 33-38.

10. Kuritsky A.B., 2002. Government regulation of the Internet economy: theory issues, world experience and prospects for its use in Russia. SPb. : SPb. University. $109 \mathrm{p}$.

11. Maksiyanova T.V., 2010. Innovation Technologies in Modern Economics. St. Petersburg. IMC "NVSh - SPb". 316 p.

12. Molokanov S. I., 2010. The use of electronic educational tools for teaching university students (for example, teaching students of the biological faculty) // Proceedings of young scientists of Altai State University [Trudy molodykh uchenykh Altaiskogo gosudarstvennogo universiteta]. No. 7. P. 338-340.

\section{About the authors:}

Alexey P. Isaev, Dean of Faculty of Economy and Finance of North-West institute of management of RANEPA (St. Petersburg, Russian Federation), Doctor of Science (History), Professor; isaevap@ranepa.ru

Tatyana V. Vasilyeva, Associate Professor of the Chair of Economics of the North-West Institute of Management of RANEPA (St. Petersburg, Russian Federation), PhD in Economics, Associate Professor; 15351538@mail.ru 


\section{Литература}

1. Васильева T.В. Информационно-образовательная сеть «SPIDER» : монография. СПб. : ИМЦ «НВШ - СПб», 2008. 112. с. (In rus)

2. Васильева Т.В. Интернет-экономика в России: монография. СПб. : ИМЦ «НВШ - СПб», 2018. (In rus)

3. Васильева Т.В. Информационно-коммуникационные технологии в системе высшего образования : монография. СПб. : ИМЦ «НВШ - СПб», 2009. (In rus)

4. Васильева Т. В. Электронное обучение в России. СПб. : ИМЦ «НВШ - СПб», 2018. (In rus)

5. Карловская Е.А., Максиянова Т.В. [и др.]. Россия в XXI веке: модель устойчивого развития : монография. Кн. 4. Новосибирск : Сибпринт, 2011. (In rus)

6. Коновалова Т.А. Методика комплексной оценки эффективности монопромышленного города (на примере г. Сосновый Бор Ленинградской области) // Дискуссия. 2012. № 10. C. 51-58. (In rus)

7. Коновалова Т.А. Особенности экономического развития моногородов стратегического значения // Казанская наука. 2012. №. 7. С. 80-83. (In rus)

8. Куганов В.Г., Козлова В.М. Перспективы рынка мобильной торговли в цифровой экономике // Экономический вектор. 2019. № 1 (16). С. 45-48. (In rus)

9. Кудряшов В.С. Реализация кластерной политики в целях экономического развития регионов России // Экономика и управление: проблемы, решения. 2017. № 1. С. 33-38. (In rus)

10. Курицкий А.Б. Государственное регулирование интернет-экономики: вопросы теории, мировой опыт и перспективы его использования в России. СПб. : СПб. университет, 2002. (In rus)

11. Максиянова Т.В. Инновационные технологии в современной экономике. СПб. : ИМЦ «НВШ - СПб», 2010. 316 с. (In rus)

12. Молоканов С.И. Применение электронных средств учебного назначения для обучения студентов вуза (на примере обучения студентов биологического факультета) // Труды молодых ученых Алтайского государственного университета. 2010. №. 7. С. 338-340. (In rus)

\section{Об авторах:}

Исаев Алексей Петрович, декан факультета экономики и финансов Северо-Западного института управления РАНХиГС (Санкт-Петербург, Российская Федерация), доктор исторических наук, профессор; isaev-ap@ranepa.ru

Васильева Татьяна Владимировна, доцент кафедры экономики Северо-Западного института управления РАНХиГС (Санкт-Петербург, Российская Федерация), кандидат экономических наук, доцент; 15351538@mail.ru 